\title{
WSPÓŁPRACA PRZEDSIĘBIORSTW Z ADMINISTRACJĄ PUBLICZNĄ NA PRZYKŁADZIE SŁUŻBY CELNEJ
}

Zarys treści: Wyzwaniem stojącym nie tylko przed administracją celną, ale także przed każdą inna administracją w państwie jest podążanie oraz często potrzeba wyprzedzania rzeczywistości gospodarczej. Polska Służba Celna podejmuje działania mające na celu wspieranie legalnej działalności gospodarczej oraz wprowadza różnego rodzaju ułatwienia i uproszczenia dla przedsiębiorców. Implementacja ułatwień dotyczy wszelkich obszarów jej działalności, do których możemy zaliczyć: przepisy prawa, wytyczne i instrukcje, systemy informatyczne, ułatwienia organizacyjne, bezpośrednie kontakty z przedsiębiorcami. Artykuł w znacznej części jest poświecony przybliżeniu programów informatycznych, które są wykorzystywane przez przedsiębiorców. Na treść rozważań ujętych w niniejszej pracy składają się również, poza podstawowymi informacjami o Służbie Celnej w Polsce, jej misja i wizja w ujęciu strategicznym oraz prezentacja administracji celnej w kontekście międzynarodowym.

Słow a kluczowe: Służba Celna; administracja publiczna; strategia; przedsiębiorcy; handel międzynarodowy.

K 1 a s y fik a c ja J E L: E61; L31.

* Adres do korespondencji: Bartosz Stelter, Uniwersytet Mikołaja Kopernika w Toruniu, Wydział Nauk Ekonomicznych i Zarządzania, Katedra Doskonałości Biznesowej, ul. Gagarina 13a, 87-100 Toruń, e-mail: stelter@doktorant.umk.pl. 


\section{WSTĘP}

Reformy administracji publicznej to proces ciągłych zmian, które zostały wywołane przez czynniki polityczno-ekonomiczne. Czynniki ekonomiczne to także potrzeba radykalnych zmian w zarządzaniu. Lata 90. to czas po kryzysach, które doświadczyły tzw. tygrysy azjatyckie, a w innych krajach, jak np. Wielka Brytania, potrzeby reform wynikały z woli przezwyciężania stagnacji. Rozwojowi gospodarczemu sprzyjają oczekiwania środowisk biznesowych, które nieustannie wzrastają i ukierunkowane są na tworzenie warunków dla rozwoju, już nie tylko w aspekcie krajowym, ale i międzynarodowym. Dzisiejsze kraje Unii Europejskiej, wśród których znajduje się także Polska, należą do tych o ogromnym potencjale. Oznacza to, że czynniki instytucjonalne, czyli określające współzależność krajów i ich gospodarek narodowych, stały się częścią światowego systemu politycznego i ekonomicznego. Współcześnie dominującą tendencją, dostrzegalną zarówno w krajach Unii Europejskiej, jaki i w krajach azjatyckich jest informatyzacja administracji. Znaczenie tych działań dla współpracy środowiska biznesowego nie jest bez znaczenia. Polska Służba Celna należąca do administracji rządowej, wpisuję się w działania, które są ukierunkowane na wspieranie, rozwój oraz obsługę podatników. Oczekiwania przedsiębiorców są jednoznaczne - redukcja kosztów, a w kontakcie z urzędem, dla przedsiębiorców liczy się czas potrzebny na załatwianie formalności. W niniejszym artykule podjęto rozważania na temat współpracy administracji celnej z przedsiębiorcami, ze szczególnym uwzględnieniem aplikacji elektronicznych. Przybliżone zostały także informacje na temat tej formacji, w aspekcie zarządzania strategicznego oraz w na tle międzynarodowym.

\section{PODSTAWOWE INFORMACJE - ZAKRES DZIAEANIA SŁUŻBY CELNEJ, AKCESJA DO UE}

Służba Celna jest jednolitą umundurowaną formacją podległą Ministrowi Finansów. Utworzona w celu zapewnienia ochrony i bezpieczeństwa obszaru celnego Wspólnoty Europejskiej, w tym zgodności z prawem przywozu towarów na ten obszar oraz wywozu towarów z tego obszaru. Wykonuje również obowiązki określone w przepisach odrębnych, w szczególności w zakresie podatku akcyzowego oraz podatku od gier [http://www.mf.gov. $\mathrm{pl} /$ sluzba-celna/dzialalnosc/zadania-i-funkcje]. Struktura organizacyjna 
Służby Celnej ${ }^{1}$ to 16 izb celnych, 46 urzędów celnych oraz 150 oddziałów celnych, w tym 50 obsługujących przejścia graniczne.

Funkcję koordynatora zadań nałożonych na Służbę Celną pełni minister właściwy do spraw finansów publicznych, który również współdziała w kształtowaniu polityki państwa w zakresie zadań Służby Celnej. Minister Finansów swoje zadania wykonuje bezpośrednio poprzez podsekretarza stanu w Ministerstwie Finansów, który jest jednocześnie Szefem Służby Celnej.

Służba Celna realizuje zadania ustawowe oraz te przewidziane porozumieniami z wieloma podmiotami administracji rządowej i samorządowej. Jednakże taką współprace można uznać za pomocniczą i zadaniową, id est pojawiającą się, gdy zaistnieje taka konieczność. W większym stopniu współpraca przebiega na linii urząd - samorząd gospodarczy oraz urząd podatnik, rozumiany jako osoba prywatna lub osoba prawna.

Istotnym z punktu widzenia zadań Służby Celnej było przystąpienie Polski do Unii Europejskiej. Proces akcesji był związany ze zniesieniem granicy celnej z sąsiadującymi państwami członkowskimi UE, tj.: Niemcami, Czechami, Słowacją i Litwą. W rezultacie akcesji nastąpił bezcłowy przepływ towarów w ramach krajów unijnych oraz znacznie wzrosło znaczenie wschodniej granicy Polski jako zewnętrznej granicy UE [http:// www.mf.gov.pl/sluzba-celna/dzialalnosc/zadania-i-funkcje]. Ponadto została zniesiona kontrola graniczna na granicach wewnętrznych oraz stosowane są ściśle określone jednolite zasady dotyczące: kontroli na granicach zewnętrznych, wzoru wiz wydawanych cudzoziemcom, wzajemnej współpracy pomiędzy służbami państw - sygnatariuszy, w szczególności w zakresie współpracy policyjnej i sądowej w sprawach kryminalnych, jak również działania tzw. Systemu Informacyjnego Schengen [https://www.msw. gov.pl/pl/wspolpraca-miedzynarod/unia-europejska/schengen/7094,dok. html]. Polska przystąpiła do strefy Schengen ${ }^{2} \mathrm{z}$ dniem 21 grudnia $2007 \mathrm{r}$. (granica lądowa i morska) i w marcu 2008 r. (porty lotnicze). Przystąpienie Polski do Unii Europejskiej oznaczało także przystąpienie do unii celnej

Więcej na temat zadań i struktury organizacyjnej Służby Celnej m.in. w Łuszczyk J., Podstawowe zasady organizacji i funkcjonowania Stużby Celnej, w: Sprawność administracji państwowej i samorządowej, red. Sikorski J., Wydawnictwo Akademii Świętokrzyskiej, Kielce 2007, s. 103-109 oraz Gołębiewski S., Obstuga celna w przeplywie towarów, Wydawnictwo Difin, Warszawa 2005, s. 386-391.

2 Strefa Schengen, układ z Schengen - porozumienie znoszące kontrolę osób przekraczających granice między państwami członkowskimi układu. 
oraz do wspólnego rynku. Oznacza to, że podmioty dokonujące obrotu towarowego mogą dokonywać odprawy celnej w każdym urzędzie celnym na terytorium Unii Europejskiej [http://www.zneiz.pb.edu.pl/data/magazine/ article/423/pl/1.6_laszuk.pdf]. Działanie takie wzmaga konkurencję i dlatego konieczne staje się ciągłe udoskonalanie procedur celnych i tworzenie klimatu sprzyjającego i zachęcającego przedsiębiorców do regulowania niezbędnych czynności urzędowych w Polsce.

Do podstawowych zadań stawianych współcześnie przed Służbami Celnymi państw członkowskich należących do Unii Europejskiej należy, m.in.:

- Pobieranie należności związanych z obrotem towarowym z krajami trzecimi.

- Ułatwianie legalnej działalności gospodarczej.

- Zwalczanie przestępczości celnej.

- Zapewnienie podstawowej wartości społeczeństwa europejskiego związanych przykładowo z ochroną obywateli przed zagrożeniami zdrowotnymi i społecznymi, strzeżenie dziedzictwa kulturowego [Witkowski, 2006, s. 224].

Funkcje, jakie realizuje Służba Celna można podzielić na cztery kategorie [Witkowski, 2006, s. 224-225]:

- Funkcja ochronno-prezencyjna, jest związana z działaniami podejmowanymi w celu ochrony wspólnego obszaru celnego Unii Europejskiej, poborem należności celnych, ochroną poziomu produkcji i zatrudnienia w wybranych obszarach gospodarki, monitorowanie wielkości przywozu i wywozu określonych towarów oraz zwalczaniem przestępczości celnej.

- Funkcja aktywizująco-informacyjna, związana jest z upowszechnianiem możliwości ułatwień i uproszczeń w zakresie formalności celnych, w szczególności odnoszących się do wywozu towarów poza wspólny obszar celny, propagowanie instytucji prawa celnego wpływającego na zwiększenie międzynarodowej konkurencji oferty m.in. własnych firm i towarów, prezentacji możliwości korzystania z instrumentów prawa celnego bez konieczności ponoszenia obciążeń finansowych, wpływając tym samym na zwiększenie płynności finansowej firm, dokłada i rzetelna informacja w zakresie przepisów prawa celnego.

- Funkcja innowacyjno-motywacyjna, mająca na celu wprowadzenie do działania administracji celnej nowych rozwiązań z zakresu rozwoju naukowo-technicznego. Związana jest z wprowadzeniem 
i praktycznym zastosowaniem instrumentów informatycznych. Funkcja ta odnosi się również do wdrażania i popularyzowania nowoczesnych technik w procesach zarządzania zasobami ludzkimi oraz w komunikacji administracji celnej.

- Funkcja koordynacyjna, oznacza aktywną i twórczą współpracę administracji celnej z innymi organami, m.in.: ze Strażą Graniczną, służbami fitosanitarnymi i weterynaryjnymi oraz środowiskiem gospodarczym.

Do funkcji administracji celnej dodana może być również funkcja promocji międzynarodowej wymiany towarowej, na którą składają się prowadzenie współpracy z organami celnymi innych państw i organizacjami międzynarodowymi w celu ułatwiania legalnego obrotu towarowego z krajami trzecimi, ułatwianie legalnej wymiany towarowej z krajami trzecimi oraz działalności gospodarczej [Struzik, 2008, s. 84-85]. Funkcje realizowane przez Służbę Celną w Polsce z powodzeniem mogą zostać zawarte w trzy zakresy, mianowicie: ochronny, kontrolny i fiskalny³.

\section{STRATEGIA, MISJA I WIZJA SŁUŻBY CELNEJ}

Zarządzenie nr 50 Ministra Finansów z dnia 13 grudnia 2013 r. w sprawie strategii działania Służby Celnej [http://www.mf.gov.pl/documents/764034/928139/zarzadzenie+nr+50+MF+w + sprawie+Strategii.pdf] jest dokumentem, na podstawie którego strategia ${ }^{4}$ działania Służby Celnej na lata 2014-2020 została określona. Zastąpiła bezpośrednio Strategię działania Służby Celnej na lata 2010-2015 z 21 maja 2010 r. Ta obecnie funkcjonująca, stanowiąca Załącznik do zarządzenia Nr 50 Ministra Finansów z dnia 13 grudnia 2013 r., została zaprezentowania w styczniu 2014 r. podczas konferencji Służby Celnej „Służba Celna 2020” [http://www. mf.gov.pl/sluzba-celna/wiadomosci/aktualnosci/-/asset_publisher/2UWl/ content/id/7414658]. Jest ona skoncentrowana na klientach Służby Celnej. W sposób szczególny na wspieraniu aktywności gospodarczej podmiotów oraz podnoszenie standardów obsługi klienta. Partnerska współpraca i sta-

3 Por. Laszuk M., Wspótpraca administracji celnej z organami administracji państwowej, samorzadowej oraz samorządem gospodarczym, „Ekonomia i Prawo”, red. Polszakiewicz B., Boehlke J., t. XII, nr 1/2013, s. 129.

4 Teoretyczne aspekty planowania strategicznego w administracji publicznej można znaleźć m.in. w: Nowy paradygmat funkcjonowania administracji publicznej, red. Figiel Sz., Kożuch A.J., Wydawnictwo IDEICO, Olsztyn 2012, s. 51-57. 
ły kontakt Służby Celnej z jej klientami i interesariuszami uwidoczniona w Strategii Działania Służba Celna 2020 jest skoncentrowana na tym, co Służba Celna oferuje na zewnątrz, a więc dla wspomnianych już przedsiębiorców, mających realny, bezpośredni kontakt z administracją celną, ale także na innych kluczowych klientach, którymi jest, holistycznie rzecz ujmując, całe społeczeństwo.

Służba Celna, będąca zainteresowana ciągłym udoskonalaniem swoich procedur, jest formacją, która dąży do tego, aby włączyć się w nurt nowego zarządzania publicznego (New Public Management), wraz z jego głównymi elementami [ $\mathrm{Na}$ podstawie: http://bialapodlaska.uc.gov.pl/?obiekt $=2819 \& \mathrm{~m}=1]$, tj.:

- współzarządzanie publiczne (Public Governance),

- zarządzanie wielopoziomowe (Multi-level Governance),

- dobre rządzenie (Good Governance)

- nowa służba publiczna (New Public Service).

- zarządzanie relacjami z klientem (Customer Relations Management)

Współczesna Służba Celna ma kilku odbiorców swoich usług: tradycyjnych - organy publiczne (jako klienci, interesariusze i partnerzy), co wynika z istoty administracji, oraz klientów (przedsiębiorcy, społeczeństwo, turyści), co jest ściśle powiązane z nurtem New Public Management i relacją cło-biznes (C2B customs-to-business).

Można wymienić nadrzędne cele przeznaczone do realizowana $\mathrm{w}$ ramach tej strategii, a są to:

- wspieranie aktywności gospodarczej podmiotów,

- podniesienie standardów obsługi klienta,

- zwiększenie bezpieczeństwa oraz ochrona rynku,

- zapewnienie efektywnego i skutecznego poboru dochodów.

Jest to także dokument, który określa kierunek i zakres zmian na lata 2014-2020. Zatem strategia jest ukierunkowana na wspieranie aktywności gospodarczej przedsiębiorców oraz podniesienie standardu obsługi klienta. Kontynuuje ona tym samym poprzednią Strategię. Filarami działań, które przyspieszają i ułatwiają obrót towarowy z zagranicą, są między innymi: programy $i$-cto oraz $i$-granica. Podjęcie przez polską administrację celną działań mających na celu budowanie relacji z biznesem w ramach programu ,3i 3 " nie tylko wpływa na kreowanie pozytywnego wizerunku

5 3i, akronim od słów: ang. Internet, Intelligence, Innovation, więcej na temat programu „3i” w Służbie Celnej: http://www.mf.gov.pl/documents/764034/928139/ inicjatywa_3i_od_modernizacji_do_innowacji.pdf 
Służby Celnej, ale także otwiera nowe możliwości współpracy biznesu oraz administracji. Wszystkie realizowane działania przyczyniają się do ułatwień w obrocie towarowym z zagranicą, a to ma bezpośredni związek z rozwojem oraz wzrostem konkurencyjności polskich przedsiębiorstw.

W porównaniu ze strategią Działania Służby Celnej 2007+ oraz wcześniejszymi z 1999 oraz 2004 roku, gdzie jako filary zostały nakreślone informatyzacja, legislacja oraz organizacja, widać nie tylko kontynuację rozwoju elektronicznego środowiska dla handlu i cła, ale także budowę lub rozbudowę systemów informatycznych administracji celnej, w tym także systemów ułatwiających przedsiębiorcom wielopłaszczyznową komunikację z urzędem [Por.: Smogorzewski, 2008].

Jako cele strategiczne zorientowane przede wszystkim na przedsiębiorców w Strategii działania Służby Celnej na lata 2014-2020 wskazano [http://www.zneiz.pb.edu.pl/data/magazine/article/423/pl/1.6_laszuk.pdf, s. 98]:

- Wspieranie aktywności gospodarczej przedsiębiorców poprzez zmniejszenie obciążeń i ograniczeń administracyjnych, zwiększenie zakresu i dostępności uproszczeń, zwiększenie przejrzystości, spójności i jednolitości stosowania prawa oraz świadomości prawnej klientów.

- Podniesienie standardów obsługi klienta obejmujące zwiększenie dostępności i poziomu e-usług, skrócenie czasu obsługi, zwiększenie stosowania ułatwień oraz zwiększenie stopnia integracji danych i usług (rejestrów/systemów IT).

- Zwiększenie bezpieczeństwa oraz ochrony rynku przez zmniejszenie udziału nielegalnych towarów akcyzowych i celnych oraz nielegalnego hazardu na rynku, zmniejszenie nielegalnego obrotu towarami niebezpiecznymi dokonywanego przez granice, zwiększenie świadomości społeczeństwa o zagrożeniach dla bezpieczeństwa i rynku.

Zadanie Służby Celnej to nie tylko właściwa relacja z obywatelami i przedsiębiorcami, rozumiana jako skuteczny system kontroli, ale przede wszystkim wspieranie i ułatwianie legalnej działalności gospodarczej oraz zabezpieczanie i chronienie społeczeństwa oraz środowiska przed zagrożeniami. Jest to możliwe do realizowania w oparciu o wysoko wykwalifikowaną kadrę, efektywne metody zarządzania i nowoczesne technologie.

Misja Służby Celnej jest odzwierciedleniem jej roli w stosunku do swoich interesariuszy. Jednoznacznie wychodzi naprzeciw potrzebom i wymaganiom stawianym przez społeczeństwo. Zgodnie z jej treścią dzia- 
ła zarówno dla dobra Rzeczypospolitej Polskiej, jak i Unii Europejskiej. Jej nadrzędne trzy zasady:

- efektywnie pobiera dochody,

- aktywnie wspiera przedsiębiorczość,

- skutecznie zwalcza oszustwa oraz chroni rynek i społeczeństwo.

Wizja Służby Celnej uzewnętrznia elementy New Public Management. Zgodnie z wizją nakreśloną w Strategii, Służba Celna będzie formacją innowacyjnie wykorzystującą wiedzę, do świadczenia lepszych usług w erze cyfrowego stylu życia [http://www.mf.gov.pl/documents/764034/1161637/ strategia+działania+SC+na+lata+2014_2020.pdf]. W ramach nowych priorytetów Służba Celna kontynuuje podejście realizowane już od pewnego czasu w ramach Inicjatywy $3 \mathrm{i}$, tj.:

- Wykorzystuje elektroniczne narzędzia i jest obecna w środowisku cyfrowym - INTERNET.

- Podejmuje działania mające na celu inteligentne wykorzystanie wiedzy - INTELLIGENCE.

- Wdraża nowe, innowacyjne rozwiązania - INNOVATION [http:// www.mf.gov.pl/documents/764034/1161637/strategia+działania+ SC+na+lata+2014_2020.pdf].

Służba Celna ułatwia działalność gospodarczą przedsiębiorcom, czego przykładem są obecnie wdrażane lub już wdrożone następujące ułatwienia [Opracowano na podstawie: http://www.mf.gov.p1/sluzba-celna/wiadomosci/aktualnosci/-/asset_publisher/2UWl/content/id/7414658]:

- Dostawa bezpośrednia jest inicjatywą umożliwiającą większą elastyczność w odprawach celnych. Jej istota sprowadza się do dostarczenia towaru bezpośrednio do odbiorcy, a nie do urzędu celnego.

Instytucja bezpośredniej dostawy jest ułatwieniem dla przedsiębiorców polegającym na możliwości dostarczenia towaru bezpośrednio do odbiorcy zamiast konieczności przedstawienia towaru w urzędzie celnym. Warunkiem skorzystania z tego ułatwienia jest uznanie przez dyrektora właściwej izby celnej lub naczelnika urzędu celnego (uznanie jednorazowe) miejsca dostarczenia towaru jako miejsca uznanego przez organ celny. Może to być np. plac firmy. Także upoważniony odbiorca w procedurze tranzytu będzie mógł w standardzie objąć towary również procedurą dopuszczenia do obrotu w miejscu uznanym, z którego na co dzień korzysta. Co więcej, 24 grudnia 2013 r. weszła w życie nowelizacja rozporządzenia ministra finansów, która uprościła wnioskowanie o uznawanie miejsc dla celów dokonywania czynności przewidzianych przepisami prawa celnego (w tym także dla potrzeb realizacji dostawy bezpośredniej). 
Przedsiębiorcy mogą uzyskać zgodę na korzystanie z tego ułatwienia: jednorazowo (uzyskując zgodę naczelnika właściwego miejscowo urzędu celnego), na okres 2 lat (uzyskując zgodę dyrektora właściwej miejscowo izby celnej), bezterminowo, w przypadku podmiotów posiadających bezterminowe pozwolenie na zakończenie tranzytu (miejsce uznane w pozwoleniu na zakończenie tranzytu jest jednocześnie uznane do następującej po tranzycie procedury celnej np. dopuszczenia do obrotu).

- Deklaracja akcyzowa on-line (e-AKC-U) bez podpisu kwalifikowanego - rozwiązanie przeznaczone jest dla osób fizycznych składających różnego rodzaju deklaracje akcyzowe. Zostało przygotowane szczególnie z myślą o podatnikach podatku akcyzowego od samochodów osobowych nabywanych w Unii Europejskiej, ponieważ takie właśnie deklaracje podatnicy składają najczęściej. Aby złożyć takie deklaracje przez Internet, osoby fizyczne nie muszą już posiadać certyfikatu kwalifikowanego podpisu elektronicznego.

Korzystanie z Elektronicznego Potwierdzenia Zapłaty Akcyzy od samochodu osobowego nabytego w krajach Unii Europejskiej, niesie za sobą niezaprzeczalne korzyści, które wpłyną korzystnie na działalność zawodową nie tylko na przedsiębiorców zajmujących się zawodowo takiego typu praktykami, ale także osoby, która jednorazowo lub sporadycznie nabywa samochód osobowy z krajów Unii Europejskiej ${ }^{6}$.

- Single Window w obrocie towarowym z zagranicą - projekt pozwala na elektroniczną wymianę informacji/danych/dokumentów pomiędzy różnymi organami administracji publicznej oraz między administracją publiczną a przedsiębiorcami. To szansa na optymalizację i skrócenie czasu czynności urzędowych, sprawną analizę ryzyka i kontrolę ukierunkowaną na zwalczanie nadużyć i nieprawidłowości.

Oczywiście wyżej wymienione przykłady nie wyczerpują całego katalogu ułatwień, jednakże nie sposób nie wymienić także instytucji upoważnionego przedsiębiorcy [www.mf.gov.pl/documents/764034/1161637/ AEO] (AEO - Authorised Economic Operator). $\mathrm{AEO}^{7}$ jest to specjalny

6 Więcej na temat korzyści z elektronicznego składania deklaracji akcyzowej m.in. na stronie Izby Celnej w Toruniu: http://www.izbacelna.torun.pl/aktualnoci/35ujawnienia/900-informacja-dla-nabywcow-samochodow-osobowych-z-ue.html oraz czynności technicznych z tym związanych: http://www.izbacelna.torun.pl/eakc-u.html

7 Więcej o AEO, m.in. w: Grottel M., Polska stużba celna w procesie podwyższania jakości usług biznesowych, Biznes międzynarodowy w gospodarce globalnej 
rodzaj uproszczenia, który został wprowadzony 1 stycznia 2008 r. Posiadanie świadectwa daje możliwość korzystania z ułatwień odnoszących się do kontroli celnej dotyczącej bezpieczeństwa, ochrony i/lub uproszczeń przewidzianych $\mathrm{w}$ ramach przepisów celnych. Upoważniony przedsiębiorca (AEO) jest to przedsiębiorca posiadający jedno ze świadectw AEO, o którym mowa w art. 14, a Rozporządzenia Wykonawczego do Wspólnotowego Kodeksu Celnego:

- świadectwo AEO - uproszczenia celne,

- świadectwo AEO - bezpieczeństwo i ochrona,

- świadectwo AEO - uproszczenia celne/bezpieczeństwo i ochrona.

Status AEO może zostać udzielony przedsiębiorcom posiadającym siedzibę na obszarze celnym Unii

Europejskiej (wyjątki określają przepisy Rozporządzenia Wykonawczego) spełniającym następujące

warunki i kryteria:

- odpowiednie przestrzeganie wymogów celnych,

- odpowiedni system zarządzania ewidencjami handlowymi (a gdzie zachodzi taka potrzeba

- ewidencjami transportowymi), który umożliwia właściwą kontrolę celną,

- udokumentowana wypłacalność,

- odpowiednie standardy bezpieczeństwa i ochrony.

Korzyści wynikające z posiadania statusu AEO są następujące:

- Status AEO przyznany w jednym państwie członkowskim Unii Europejskiej jest uznawany w całej Unii Europejskiej oraz niektórych krajach trzecich m.in. w Japonii i USA.

- Status AEO uprawnia także do korzystania z ułatwień odnoszących się do kontroli celnej.

W zakresie kontroli celnej dotyczącej bezpieczeństwa i ochrony przedsiębiorca może korzystać z

następujących ułatwień:

- Podlega mniejszej niż inni przedsiębiorcy liczbie kontroli fizycznych i kontroli dokumentów.

2014, nr 33, s. 715 oraz Szmyd K., Kryteria oceny efektywności polskich stużb celnych $w$ odprawie celnej $w$ obrotach handlu zagranicznego, Contemporary Economy, Electronic Scientific Journal. http://cejsh.icm.edu.pl/cejsh/element/bwmeta1.element. desklight-52c68046-3cbd-4657-a0b6-7ef65cd5af79, s. 6. 
- W przypadku wytypowania go do kontroli, przeprowadzana jest ona w sposób priorytetowy.

- Uprawnienia do wcześniejszego powiadomienia o wytypowaniu przesyłki do kontroli.

- Uprawnienia do składania przywozowej deklaracji skróconej z ograniczonym zakresem

- Wymaganych danych bezpieczeństwa.

- Możliwości wnioskowania o przeprowadzenie kontroli w innym miejscu niż urząd celny.

W przypadku złożenia przez upoważnionego przedsiębiorcę wniosku o stosowanie uproszczeń

wymienionych w Rozporządzeniu Wykonawczym organy celne nie badają ponownie tych warunków,

które już były badane przy przyznawaniu świadectwa AEO. W Polsce do końca 2013 r. wydanych zostało 712 świadectw AEO i Polska jest jednym $\mathrm{z}$ liderów w UE w tym obszarze (zajmujemy 5 miejsce w UE pod względem liczby wydanych świadectw po Niemczech, Holandii, Włoszech, i Francji).

Analizując powyższe przykłady, można konstatować, że przyniosą następujące korzyści przedsiębiorcom [http://www.zneiz.pb.edu.pl/data/magazine/article/423/pl/1.6_laszuk.pdf, s. 102]:

- Skrócenie czasu potrzebnego przedsiębiorcy na załatwianie formalności.

- Ograniczenie wykonywania przez Służbę Celną stałych kontroli przedsiębiorców.

- Podniesienie jakości i efektywności świadczonych usług związanych bezpośrednio z obsługą spraw interesantów.

- Zwiększenie przejrzystości procedur administracyjnych, a w konsekwencji wzrost zaufania przedsiębiorców do administracji publicznej.

\section{ELEKTRONICZNE ŚWIADCZENIE USŁUG PRZEZ SŁUŻBĘ CELNA}

W pewnych sytuacjach konieczna jest fizyczna obecność przedsiębiorcy w urzędzie. Niemniej jednak, także i to jest coraz częstsza praktyka, podatnik dokonuje czynności urzędowych zdalnie poprzez programy informatyczne. Wiąże się to ze skracaniem czasu obsługi, a to przekłada się 
na oszczędność czasu i ograniczanie kosztów. Katalog programów informatycznych Służby Celnej wspierających przedsiębiorstwa jest bogaty [http://www.icwroclaw.pl/_Srodek/infrastruktura_IT.pdf]. Na wyróżnienie zasługują natomiast następujące aplikacje:

- ECS/ ICS. System ECS jest systemem wspólnotowym, umożliwiającym wymianę zgłoszenia wywozowego i wymianę informacji $\mathrm{w}$ formie elektronicznej między urzędami celnymi na terenie Unii Europejskiej. Umożliwia m.in. awizowanie wysyłki towarów do urzędu celnego granicznego i zwrotne informowanie urzędu celnego wywozu o wyprowadzeniu towarów z obszaru celnego Wspólnoty. Elektroniczne potwierdzenie wyprowadzenia towarów przesyłane z urzędu wywozu do zgłaszającego zastępuje kartę 3 SAD i służy jako dokument potwierdzający wywóz towarów dla celów podatku VAT. System zapewnia administracji celnej skuteczne sprawowanie dozoru celnego, a eksporterom umożliwia znacznie szybsze udokumentowanie wywozu towarów i zastosowanie stawki podatku w wysokości $0 \%$ z tytułu eksportu towarów. System ICS jest systemem zbudowanym w oparciu o założenia wspólnotowe, umożliwiającym przedsiębiorcom realizację obowiązku wyprzedzającego przesyłania w formie elektronicznej komunikatów przywozowych deklaracji skróconych. Przywozowe deklaracje skrócone (PDS) przesyłane są dla towarów, które mają być wprowadzone na obszar celny Unii Europejskiej z krajów trzecich, w celu przeprowadzania przez organy celne analizy ryzyka pod kątem ochrony i bezpieczeństwa, opartej o wspólne dla wszystkich państw członkowskich Unii Europejskiej kryteria i standardy.

- System Obsługi Deklaracji CELINA [http://www.finanse.mf.gov. $\mathrm{pl} /$ systemy-informatyczne/celina/o-systemie; https://www.e-clo. pl/o-systemie-celina]. CELINA jest krajowym systemem służącym $\mathrm{w}$ administracji celnej do rejestracji i przetwarzania danych ze zgłoszeń celnych i innych dokumentów celnych dotyczących towarów importowanych na obszar celny Unii Europejskiej. W systemie tym obsługiwane są przede wszystkim zgłoszenia celne w zakresie procedury dopuszczenia do obrotu, uszlachetniania czynnego, składu celnego, odprawy czasowej i przetwarzania pod kontrolą celną, a także rejestrowane są deklaracje skrócone do czasowego składowania oraz powiadomienia wymagane $\mathrm{w}$ ramach realizacji procedury uproszczonej w miejscu. 
W chwili obecnej importowe zgłoszenia celne mogą być przekazywane w następującej formie:

- komunikatu elektronicznego podpisanego kluczem do bezpiecznej transmisji danych,

- zgłoszenia celnego na formularzu SAD (forma wyłącznie papierowa).

System CELINA wspomaga pracę organów celnych nie tylko w zakresie obsługi zgłoszeń celnych. Od 1 maja 2004 r. jego funkcjonalność została rozszerzona. Oprócz obsługi zgłoszeń celnych jest on również wykorzystywany m.in. do rejestrowania i przetwarzania danych pochodzących z przekazywanych organom celnym elektronicznych deklaracji INTRASTAT, tj. deklaracji ułatwienia i przyspieszenia obsługi zgłoszeń celnych. System CELINA działa we wszystkich placówkach celnych (urzędach i oddziałach celnych).

Komunikacja z podmiotami (zgłaszającymi) zapewniona jest poprzez strony webowe CELINA WEB-CEL (dla procedur standardowych) i CELINA OPUS (dla procedur uproszczonych), tworzące tzw. Wrota Celne (customs gateway). Ponadto istnieje możliwość korzystania przez podmioty z poczty elektronicznej lub dyskietki/płyty CD a także możliwość złożenia zgłoszenia w formie dokumentu papierowego, z którego dane są wprowadzane do systemu CELINA przez funkcjonariusza celnego.

- NCTS [http://www.finanse.mf.gov.pl/systemy-informatyczne/ncts/osystemie]. Nowy Skomputeryzowany System Tranzytowy (NCTS), stosowany we wszystkich krajach UE i EFTA, służy do obsługi operacji tranzytowych realizowanych w ramach tranzytu wspólnotowego/wspólnego, jak również wspomaga obsługę operacji TIR. System NCTS umożliwia składanie elektronicznego zgłoszenia do procedury tranzytu oraz wymianę informacji o operacji tranzytowej w czasie rzeczywistym za pomocą elektronicznych komunikatów, pomiędzy urzędami celnymi w obszarze międzynarodowym, krajowym, a także pomiędzy urzędami celnymi a podmiotami. System posiada architekturę klient/serwer składającą się z centralnego węzła do zarządzania i administrowania systemem na całym obszarze Polski, oraz sieć użytkowników systemu, tj. funkcjonariuszy celnych. Firmy w celu komunikacji z NCTS korzystają z oprogramowania komercyjnego budowanego na podstawie udostępnionych przez administrację celną specyfikacji XML.

W serwisie internetowym Komisji Europejskiej dostępne są następujące informacje - usługi dotyczące systemu NCTS: 
- Baza Transit - MRN Follow-up information umożliwiająca śledzenie stanu operacji tranzytowej na podstawie numeru MRN (dotyczy tylko międzynarodowych operacji tranzytowych).

- Baza Transit Customs Offices zawierająca dane o urzędach celnych właściwych do obsługi procedur tranzytu wspólnotowego/wspólnego w krajach UE/EFTA.

- EORI [http://www.e-clo.pl/files/eori/informacje_ogolne.html; http:// www.finanse.mf.gov.pl/clo-informacje-dla-przedsiebiorcow/eori/informacje-podstawowe]. Wspólnotowy System Rejestracji i Identyfikacji Podmiotów Gospodarczych (Economic Operators'Registration and Identification), zwany systemem EORI, jest jedną z części składowych tworzonego w Unii Europejskiej środowiska elektronicznego cła powstającego w ramach programu e-Customs. Środowiska dla administracji celnych i handlu w UE, w którym odchodzi się od formy papierowej dokumentów. Każdy z krajów członkowskich UE opracowuje swój własny krajowy system EORI, będzie on częścią systemu wspólnotowego EORI. System EORI w Polsce jest realizowany w Ministerstwie Finansów w Departamencie Służby Celnej na potrzeby Polskiej Administracji Celnej. Głównym celem systemu EORI jest przyspieszenie załatwiania formalności i operacji celnych przez przedsiębiorców i osoby fizyczne prowadzące działalność gospodarczą, uczestniczące w czynnościach celnych. Przedsiębiorcy podlegają jednokrotnej, po czym zostanie im nadany unikalny numer identyfikacyjny EORI. Przedsiębiorcy będą obowiązani posługiwać się tym jednym, uznawanym na obszarze całej UE numerem EORI, we wszystkich transakcjach i czynnościach celnych na obszarze UE, przy których wymagany jest ich identyfikator.

W przyszłości System EORI ma spełniać rolę systemu wspomagającego również inne systemy informatyczne administracji państw członkowskich (np. administracji podatkowych, organów weterynaryjnych, służb fitosanitarnych itp.).

\section{KONTEKST MIĘDZYNARODOWY I ROZWÓJ E-ADMINISTRACJI}

Przykłady wdrażania rozwiązań e-government w wielu krajach świata wykazują ogromne korzyści, które nich wynikają. Korzyści po stronie urzędów można podzielić na trzy grupy: 
- korzyści finansowe,

- oszczędność czasu,

- podniesienie jakości usług.

Korzyści po stronie interesantów wyglądają podobnie i są to oszczędność czasu i pieniędzy niezbędnych do tego, aby dokonać formalnych czynności w urzędzie [Zalewski, 2007, s. 56].

Według rankingu ONZ z 2012 r. Korea Południowa była najbardziej zaawansowanym na świecie państwem pod względem wykorzystania technologii informatycznych $\mathrm{w}$ administracji publicznej [Hensel, 2012, s. 171]. Również w raporcie opublikowanym w 2014 roku [http://unpan3.un.org/ egovkb/Reports/UN-E-Government-Survey-2014; http://www.mg.gov.pl/ node/21162] Republika Korei plasuje się na pierwszym miejscu, wyprzedzając takie kraje, jak: Francja, Japonia czy Stany Zjednoczone.

Sukces ten w znacznej mierze należy upatrywać w decyzjach podjętych w połowie lat 80 . XX wieku dotyczących budowy narodowego systemu informacyjnego. Dzięki temu wszystkie działania administracji publicznej są objęte technologiami informatycznymi, a większość transakcji między obywatelami a państwem jest realizowana przy pomocy sieci informatycznych. Również koreańska służba celna [http://www.customs.go.kr/kcshome/site/ index.do?layoutSiteId=english] wykorzystuje komputerowe metody realizowania przewidzianych dla nich czynności, dzięki temu czas związany z obsługą międzynarodowej obsługi handlowej został skrócony. Czas trwania formalnych czynności, jakie są konieczne do eksportu produktu, został skrócony z jednego dnia do dwóch minut. Podobnie ma się rzecz z importem towarów, tutaj czas został zredukowany z ponad dwóch dni do dwóch godzin. Skrócenie czasu obsługi dotyczy nie tylko koreańskiej służby celnej, ale także innych państwowych instytucji takich jak np. urzędy skarbowe.

Przyglądając się mapie Europy [http://www.egov.pl/wizualizacja/poziom-rozwoju-e-government-na-mapie-europy], która przedstawia zróżnicowanie poziomu rozwoju eGovernment na tym kontynencie, należy zauważyć, że Polska, w trzystopniowej skali, uzyskała średni poziom rozwoju. Dla porównania Niemcy - wysoki, Ukraina - niski poziom rozwoju. Jako punkt odniesienia przyjęto właśnie wskaźnik rozwoju eGovernment z roku 2012 opublikowany w raporcie ONZ E-Government Survey 2012.

W październiku 2014 r. został wydany raport $^{8}$ na temat wdrażania elektronicznej obsługi w administracji celnej w krajach Unii Europejskiej.

8 THE ELECTRONIC CUSTOMS IMPLEMENTATION IN THE EU REPORT, Flash Eurobarometer 399, Fieldwork: April-May 2014 Publication: October 2014. Eu- 
Zostało tam wskazane m.in., że we wszystkich 17 krajach, które zostały poddane badaniu, ponad $50 \%$ respondentów twierdzi, że wprowadzenie elektronicznej obsługi celnej miał pozytywny wpływ na ich firmę. Jednakże występują pewne różnice w poziomie odpowiedzi na to pytanie. Ponad czterech na pięciu respondentów twierdzi, że był to pozytywny wpływ, największy odsetek pozytywnych odpowiedzi - 89\% - został udzielony w Polsce, Rumunia (84\%), Niemcy (83\%), Belgii (82\%) i Grecja (82\%). Ale mniej niż sześciu na dziesięciu respondentów twierdzi tak w Szwecji (53\%) i Danii (59\%) [http://ec.europa.eu/public_opinion/flash/fl_399_ en.pdf, s. 7].

W pięciu krajach większość respondentów uznało, że czas potrzebny na odprawę celną spadł w ciągu ostatnich pięciu lat: Polska (51\%), Litwa (50\%), Łotwa (48\%), Rumunia (43\%) oraz w Estonii (42\%). W kolejnym pytaniu większość respondentów uważa, że czas potrzebny na odprawę celną pozostał taki sam, dotyczy to Wielkiej Brytanii (58\%) i Szwecji (56\%) [http://ec.europa.eu/public_opinion/flash/fl_399_en.pdf, s. 12]. Również w dziale dotyczącym wpływu elektronicznych procedur celnych na działalność przedsiębiorstwa najwyższy odsetek respondentów deklarujących uproszczenie procedur celnych, w związku z przejściem od formy papierowej do elektronicznej, znalazł się w Polsce (79\%), na dalszym miejscu Bułgaria, Litwa i Rumunia (po 68\%) [http://ec.europa.eu/public_opinion/ flash/fl_399_en.pdf, s. 53].

Można przyjąć, że światowe tendencje rozwoju administracji ukierunkowane są na elektroniczną obsługę klienta, tj. obsługę poprzez środki zdalnego dostępu z każdego miejsca w którym podatnik

\section{PODSUMOWANIE}

Analizując literaturę przedmiotu, należy zauważyć istniejącą tendencję wzrostową do poruszania w opracowaniach naukowych, nie tylko opisu zasad i funkcjonowania samej administracji publicznej, ale także korelacji występującej między administracją a przedsiębiorcami oraz ogólniej między administracją a jej otoczeniem. Tendencja ta występuje również

robarometr jest międzynarodowym projektem regularnego badania opinii publicznej realizowanym na zlecenie Komisji Europejskiej. Niniejszy raport dotyczy wdrażania elektronicznych usług dla przedsiębiorców przez administracje celne UE. 
w obszarze, który dotyczy szczególnej i specyficznej działalności, jaka jest określona zadaniami i funkcjami Służby Celnej.

Źródłami wykorzystanymi przy pisaniu niniejszego opracowania była literatura dotycząca administracji publicznej oraz jej miejsca w makrootoczeniu gospodarczym, informacje dostępne na stronach internetowych, w szczególności Ministerstwa Finansów, izb celnych w Polsce (Biuletyn Informacji Publicznej) oraz publikacje branżowe (Wiadomości Celne), opracowania, artykuły naukowe traktujące ściśle o tematyce współpracy służby celnej z podmiotami gospodarki rynkowej oraz raporty uwzględniające ilościowy i statystyczny kontekst polskiej służby celnej spośród krajów Unii Europejskiej. Jedną z konkluzji może być stwierdzenie, że tematyka szeroko pojętej administracji publicznej oraz, in particular, jej roli w biznesie jest coraz częściej rozważana. Intencją autora było wpisanie się w ten nurt, w szczególności przybliżenie roli i zadań administracji publicznej na przykładzie Służby Celnej w Polsce.

Funkcja ekonomiczna administracji celnej to nie tylko naliczanie i pobór należności celnych oraz podatkowych, ale ścisły związek gospodarczy z przedsiębiorcami oparty również na zasadzie administrowania. Współpraca ta, stanowiąca wycinek działań podejmowanych przez polską Służbę Celną, wspólnie z funkcją ochronną, jaką jest zwalczanie przestępczości celnej oraz pozostałymi funkcjami, daje dopiero relatywnie pełny obraz działań i czynności podejmowanych i koordynowanych przez celników.

\section{LITERATURA}

Nowy paradygmat funkcjonowania administracji publicznej, red. Figiel Sz., Kożuch A.J. Wydawnictwo IDEICO, Olsztyn 2012.

Gołębiewski S., Obstuga celna w przeptywie towarów, Wydawnictwo Difin, Warszawa 2005.

Hensel P., Sektor publiczny - specyfika i metody zarzadzania, w: Nowe kierunki $w$ organizacji i zarzadzaniu: organizacje, konteksty, procesy zarzadzania, red. Glinka B., Kostera M., Oficyna Wolters Kluwer Business, Warszawa 2012.

Kożuch B., Zarzadzanie publiczne. W teorii i praktyce polskich organizacji, Wydawnictwo PLACET, Warszawa 2004.

Laszuk M., Wspótpraca administracji celnej z organami administracji państwowej, samorzadowej 
oraz samorządem gospodarczym, „Ekonomia i Prawo”, red. Polszakiewicz B., Boehlke J.,

t. XII, nr 1/2013.

Łuszczyk J., Podstawowe zasady organizacji i funkcjonowania Stużby Celnej, w: Sprawność administracji państwowej i samorzadowej, red. Sikorski J., Wydawnictwo Akademii Świętokrzyskiej, Kielce 2007.

Modzelewski P., Systemy zarządzania jakościa a skuteczność i efektywność administracji samorzqdowej, CeDeWu Sp. z o.o., Warszawa 2009.

Smogorzewski G., Informatyzacja administracji celnej, w: Podstawy celnictwa, red. Jura J., Wydawnictwo Wyższej Szkoły Cła i Logistyki, Warszawa 2008.

Struzik A., Polska administracja celna, w: Podstawy celnictwa, red. Jura J., Wydawnictwo Wyższej Szkoły Cła i Logistyki, Warszawa 2008.

Witkowski P., Zarządzanie jakościa w polskiej Stużbie Celnej - wybrane aspekty praktyczne na przykładzie Izby Celnej w Białej Podlaskiej, w: Organizacja, zarzadzanie i finansowanie administracji publicznej, red. Borowski J., Sikorski J., Wydawnictwo Uniwersytetu w Białymstoku, Białystok 2006.

Nowe zarzadzanie publiczne $w$ polskim samorzadzie terytorialnym, red. Zalewski A., Szkoła Główna Handlowa w Warszawie, Warszawa 2007.

Źródła internetowe:

Elastyczność dokonywania odpraw celnych

http://www.mf.gov.pl/documents/764034/928139/elestycznosc+odpraw.pdf [dostęp: 05.05.2015]

Filipiuk J., New Public Management - nowa filozofia zarzadzania sektorem publicznym,

http://www.aglomeracja.holdikom.com.pl/LinkClick.aspx?fileticket=DpphbwsNErQ\%3D\&tabid=354 [dostęp: 05.05.2015]

Grottel M., Polska stużba celna w procesie podwyższania jakości ustug biznesowych, Biznes międzynarodowy w gospodarce globalnej 2014, nr 33

http://yadda.icm.edu.pl/yadda/element/bwmeta1.element.ekon-element-000171323045 [dostęp: 05.05.2015]

Laszuk M., Działania Stużby Celnej w zakresie wspierania przedsiębiorczości wynikajace ze Strategii działania Stużby Celnej na lata 2014-2020

http://www.zneiz.pb.edu.pl/data/magazine/article/423/pl/1.6_laszuk.pdf [dostęp: 11.05.2015] 
Newsletter 1, nr 01/2014

http://www.iph.rzeszow.pl/celneNL.pdf [dostęp: 05.05.2015]

Niedźwiecki J., Funkcjonowanie Polskiej Stużby Celnej we współczesnej gospodarce, „Studia i Prace Wydziału Nauk Ekonomicznych I Zarządzania”, nr 27, Uniwersytet Szczeciński

http://www.wneiz.pl/nauka_wneiz/sip/sip27-2012/SiP-27-29.pdf [dostęp: 15.05.2015]

Rejestr EORI

http://www.e-clo.pl/files/eori/informacje_ogolne.html [dostęp: 05.05.2015]

Stużba Celna 3i od modernizacji do innowacji

http://www.mf.gov.pl/documents/764034/928139/inicjatywa_3i_od_modernizacji_do_innowacji.pdf [dostęp: 05.05.2015]

Strategia działania Stużby Celnej na lata 2014-2020

http://www.mf.gov.pl/documents/764034/1161637/strategia+działania+SC+na+lata+2014_2020.pdf [dostęp: 05.05.2015]

Szmyd K., Kryteria oceny efektywności polskich stużb celnych w odprawie celnej w obrotach handlu zagranicznego, Contemporary Economy, Electronic Scientific Journal.

http://cejsh.icm.edu.pl/cejsh/element/bwmeta1.element.desklight-52c68046-3cbd-4657-a0b6-7ef65cd5af79 [dostęp: 05.05.2015]

THE ELECTRONIC CUSTOMS IMPLEMENTATION IN THE EU REPORT, Flash Eurobarometer 399, Fieldwork: April-May 2014 Publication: October 2014

http://ec.europa.eu/public_opinion/flash/fl_399_en.pdf [dostęp: 15.05.2015]

Wiadomości Celne nr 8-9/2012

http://www.mf.gov.pl/documents/764034/1395261/wiadomosci_celne_8-9_2012. pdf [dostęp: 05.05.2015]

Wiadomości Celne nr 10/2013

http://www.mf.gov.pl/documents/764034/1395261/Wiadomosci+celne+nt.+stateg ii + działania + SC+na+lata+2014+-+2020 [dostęp: 05.05.2015]

http:/unpan3.un.org/egovkb/Reports/UN-E-Government-Survey-2014 [dostęp: 05.05.2015]

http://www.customs.go.kr/kcshome/site/index.do?layoutSiteId=english [dostęp: 05.05.2015]

http://www.egov.pl/wizualizacja/poziom-rozwoju-e-government-na-mapie-europy [dostęp: 05.05.2015]

http://www.mg.gov.pl/node/21162 [dostęp: 05.05.2015] 


\title{
COOPERATION BETWEEN BUSINESSES AND PUBLIC ADMINISTRATION ON THE EXAMPLE OF THE CUSTOMS SERVICE
}

\begin{abstract}
Customs Service actively supports entrepreneurs consistently and systematically raises standards of customer service. These are the most important strategic objectives of the Customs Service, in part through: increasing the scope and availability of simplification, shortening the service time, increase the use of facilities and increase the availability of e-services. The efforts of the Customs Service in this regard have been noticed and positively evaluated also by international institutions. European Commission announced that the European Union is Polish entrepreneurs are most satisfied with e-services implemented by the Polish Customs Service. According to a report published in October KE: Flash Eurobarometer 399 "The implementation directory of electronic customs in the European Union". Businesses most appreciated Customs Service in the category of the impact of electronic services to simplify customs procedures and causing a reduction in operating costs of enterprises. In these two categories Poland found itself in first place in the European Union.
\end{abstract}

Keywords: Customs Service; Public Administration; strategy; business; international trade. 